\title{
A BALESETI GÓCHELYEK ÉS AZ INFRASTRUKTÚRA KÖZÖTTI KAPCSOLAT VIZSGÁLATÁNAK ALAPJAI
}

\section{THE RELATIONSHIP BETWEEN THE ACCIDENT BLACK-SPOT AND INFRASTRUCTURE INVESTIGATION BASICS}

\author{
Andrejszki Tamás ${ }^{1}$, Baranyai Dávid ${ }^{2}$, Török Ádám ${ }^{3}$ \\ Budapesti Müszaki és Gazdaságtudományi Egyetem, Közlekedésüzemi és \\ Közlekedésgazdasági Tanszék, Cím: 1111, Magyarország, Budapest, Stoczek 2., \\ Telefon / Fax: +36-1-463-1051 \\ 'tamas.andrejszki@mail.bme.hu \\ ${ }^{2}$ david.baranyai@mail.bme.hu \\ 3torok.adam@mail.bme.hu
}

\begin{abstract}
In Our previous researches we met with blackspots. We created an algorithm which by we can specify the blackspots of the pedestrians and cyclists in Hungary. In order to find the relationship between these accidents and the infrastructure we become familiar with the spatial autocorrelation. In this article we would like to introduce the essence of the spatial autocorrelation from correlation to autocorrelation
\end{abstract}

Keywords: traffic safety, black-spot, infrastructure, correlation.

\section{Összefoglalás}

Korábbi kutatásainkban megismerkedtünk a góchelykutatással. Készítettünk egy algoritmust, amellyel meghatároztuk a magyarországi gyalogos és kerékpáros góchelyeket. Az itt található balesetek és az infrastruktúra kialakítás közötti kapcsolat feltárása érdekében megismerkedtünk a térbeli autokorreláció módszerével. Jelen cikkben a korrelációtól kezdve, az autokorreláción keresztül szeretnénk bemutatni a térbeli autokorreláció lényegét.

Kulcsszavak: közlekedésbiztonság, góchely, infrastruktúra, korreláció.

\section{Előzetes eredményeink a góchelykutatásban}

Korábbi kutatások során a 2012-2014-es magyarországi balesetek viszonyában góchelykutatást végeztünk, amelyben azokat az eseteket vizsgáltuk, melyben érintett volt gyalogos és kerékpáros. Két technikát elemeztünk, a mozgóablakosat és a klaszteranalízist. Utóbbit találtuk alkalmasabbnak, ezért kidolgoztunk egy klaszteranalízis teljes lánc módszerén alapuló távolságmátrixos módszert. [1] [2]

\subsection{Góchelykutatásunk menete}

Góchelykutatásunk menete következőképpen alakult:
- Alaptérkép felvétele
ArcGIS térinformatikai szoftverben
- Magyarország úthálózatának kialakítása ArcGIS-ban 
- Vizsgálandó 3 év (2012-2014) baleseteinek felvétele GPS koordináta alapján

- Gyalogos és kerékpáros balesetek leszürése

- Általunk vizsgált útkategóriákon lévő balesetek leválogatása

- Balesetek szétválogatása kül- és belterületire

- Gócgyanús helyek feltárása, az általunk készített távolságmátrix-szal

- Góchelyek térképes vizsgálata

- Valós góchelyek megtalálása

Góchelykutatás során az OKA adatait használtuk fel, amelyeket MS Excel és SPSS statisztikai szoftver segítségével kezeltünk és értékeltünk. A balesetek és góchelyek térképes megjelenítésére az ArcGIS térinformatikai szoftvert alkalmaztuk.

A góchelykutatás eredményként 21 belterületi és 0 külterületi gyalogos és kerékpáros góchelyet találtunk, amelyek a következő ábrán figyelhetőek meg.

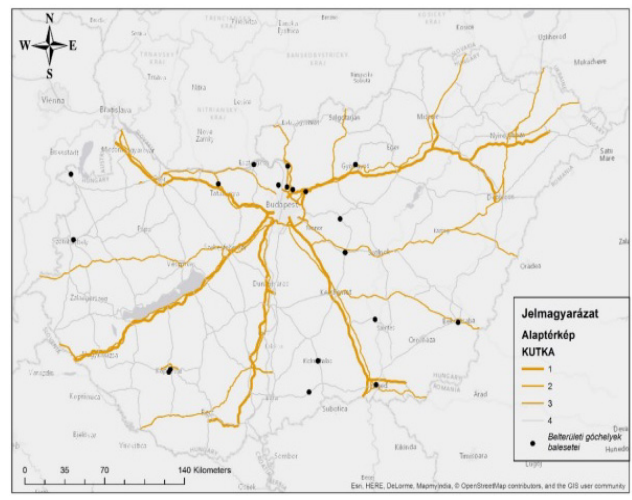

1. ábra. Magyarországi gyalogos és kerékpáros góchelyek (2012-2014)

Az egyes balesetek és az infrastruktúra kialakítás közötti kapcsolat feltárása érdekében megismerkedtünk a térbeli autokorreláció módszerével, amelyet a következő fejezetben szeretnénk bemutatni.

\section{Korreláció}

A korrelációval két változó mennyiség (függő- (eredmény) és független (magyarázó) változó) közötti kapcsolat szorosságát és irányát lehet vizsgálni. Többféle korrelációt ismerünk, pl.: előjelkorreláció, rangkorreláció, de a legelterjedtebb mérőszám a Pearson-féle korrelációs együttható.

Jelölések:

- független változó $=X$

- függő változó $=\mathrm{Y}$

- Pearson-féle korrelációs mutató $=\mathrm{R}(\mathrm{X}, \mathrm{Y})$

Értéke: $-1 \leq \mathrm{R}(\mathrm{X}, \mathrm{Y}) \leq 1$

A kapcsolat erőssége:

- gyenge: $-0,3-0,3$ között

- közepes: -0,7- -0,3 és 0,3-0,7 között

- erős: $-1--0,7$ és $0,7-1$ között

Iránya:

- pozitív: nagyobb függő változó $(\mathrm{X})$ értékekhez nagyobb független változó értékek (Y) tartoznak (2. ábra)

- negatív: nagyobb független változó $(\mathrm{X})$ értékekhez, kisebb függő változó értékek $(\mathrm{Y})$ tartoznak (3. ábra)

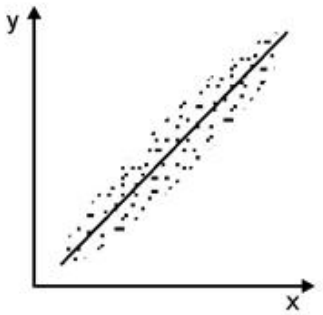

2. ábra. Példa pozitív irányú korrelációra

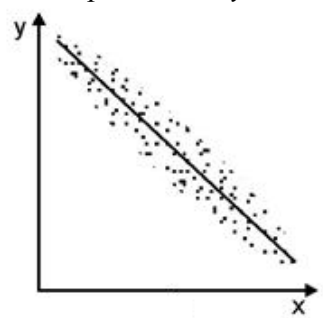

3. ábra. Példa negatív irányú korrelációra 


\section{Autókorreláció}

Az autokorreláció egy szokásos (lineáris) korreláció, csak éppen nem különböző, hanem azonos változók, máskor vagy máshol megfigyelt értékei között [3]. $\mathrm{Az}$ autokorreláció leggyakoribb előfordulása az idősorokban figyelhetö meg, ahol egy változó saját késleltetett értékeivel vett összefüggéseit méri. (az „auto" utal arra, hogy - az idősor szintjén „önmagával vett” korrelációról van szó). Ebben az esetben az adatok sorrendje kötött. A keresztmetszeti adatok sorrendje változtatható, ekkor a homoszkedaszticitást szoktuk vizsgálni [4]. Ha keresztmetszeti adatoknál fordul elő, hogy a szomszédos hibatagok korrelálnak egymással, akkor azt térbeli (területi) korrelációnak nevezik.

\section{Térbeli autókorreláció}

A regionális tudomány egyik alapvető kérdése, hogy egy-egy jelenség adott területegységen való megjelenése mennyire hasonló, illetve különböző a szomszédos területegységek értékeihez képest. [5]

A balesetek térbeli sürüsödése egymással szomszédos egységekbe is történhet, tehát már nem különálló, diszkrét elemei, hanem egymással kapcsolatban levő egységek, ahol a kapcsolatot a térbeli közelség-távolság határozza meg. Ebben az esetben térbeli autokorrelációt mérünk, azaz azt vizsgáljuk, hogy a szomszédos területi egységek adatai hasonlók vagy eltérők. Ha a területi egységek közötti térbeli kapcsolatokat figyelembe vesszük. Ekkor területi autokorrelációt mérünk, vagyis a szomszédos adatok hasonlóságát vizsgáljuk. Ennek megfelelöen például a következő mutatók állnak rendelkezésre: a lokális és globális Moran-index, Geary-féle c mutató, a Getis-Ord-féle Gi és Gi* mutatók. [6] [7]

\subsection{Moran-index}

Moran által 1948-ban javasolt mérőszám azt mutatja meg, hogy az aktuálisan vizsgált adatértékek térbeli eloszlása utal-e valamiféle szabályszerüségre, vagyis a szomszédos területegységek adatai egymáshoz hasonlók-e [6]. Értékek közötti területi autokorrelációs együttható (1):

$$
I=\frac{N}{\sum_{i} \sum_{j} w_{i j}} \frac{\sum_{i} \sum_{j} w_{i j}\left(X_{i}-\bar{X}\right)\left(X_{j}-\bar{X}\right)}{\sum_{i}\left(X_{i}-\bar{X}\right)^{2}}
$$

ahol:

$-\mathrm{N}$ az i és $\mathrm{j}$ indexelt területegységek száma,

- az Xi és Xj a területegységekhez tartozó értékek,

- az X az ezekhez az értékekhez tartozó átlagok,

- a wij a szomszédsági kapcsolatokat leíró súlymátrix eleme.

A mutató az alábbi tartományokban a következő módon értelmezendő:

$-\mathrm{I}>0$ pozitív térbeli autokorreláció

$-I=0$ nincs térbeli autokorreláció

$-\mathrm{I}<0$ negatív térbeli autokorreláció

A véletlenszerű térbeli eloszlást a 0 -hoz közeli értékek jelzik. Nem olyan egyértelmüen adható meg a szélsőértékek nagysága, mint a korrelációs együtthatónál, mivel nagyságuk függ a wij súlymátrixban rögzített területi konfigurációtól is. A maximális értéket, azaz az 1-et, végtelen vagy folytonos tér esetén érheti el, illetve ha a vizsgált terület két, belsőleg homogén, de egymással szomszédsági kapcsolatban nem álló területegységre oszlik. A minimuma szintén a végtelenben közelít a -1-hez. A -1hez közelítő értékek tökéletes diszperziót, míg a +1-hez közelítő értékek tökéletes korrelációt jelentenek. [8]

\subsection{Geary-féle $C$}

A Geary által 1954-ben publikált mutatószám a Moran-indextöl abban tér el, hogy négyzetes különbségeken alapszik. [9]

$$
C=\frac{(N-1) \sum_{i} \sum_{j} w_{i j}\left(X_{i}-X_{j}\right)^{2}}{2 W \sum_{i}\left(X_{i}-\bar{X}\right)^{2}}
$$


ahol:

-az $\mathrm{N}$ az i-vel és j-vel indexelt területegységek száma,

- X a területegységekhez tartozó értékek,

- X az ezekhez az értékekhez tartozó átlagok,

- wij a szomszédsági kapcsolatokat leíró súlymátrix elemei,

$-\mathrm{W}$ a wij súlyok összege.

A mutató a következő értékeket veheti fel:

$-\mathrm{C}<1$ pozitív térbeli autokorreláció

$-\mathrm{C}=1$ nincs térbeli autokorreláció

$-\mathrm{C}>1$ negatív térbeli autokorreláció

\subsection{Szomszédsági mátrix}

A térbeli autokorreláció számításának elöfeltétele, hogy megállapítsuk a szomszédossági kapcsolatokat és összeállítsuk a szomszédossági mátrixot. Utóbbi $\mathrm{N}$ sorból és $\mathrm{N}$ oszlopból épül fel, i-edik sorának j-edik elemének értéke az i-edik és j-edik területegység szomszédságának hiányában 0 , szomszédságuk esetén 0 -tól különböző. A megállapodás szerint a területegységek saját maguknak nem szomszédjaik, vagyis a mátrix diagonális elemei nullák. [7]

\section{Következtetések}

Korábbi kutatásainkban meghatároztuk a magyarországi gyalogos és kerékpáros baleseti góchelyeket az általunk készített klaszteranalízisen alapuló távolságmátrix módszerrel. Vizsgáltuk ezen balesetek és az infrastruktúra közötti kapcsolat mikéntjét. Erre alkalmas módszernek a térbeli autokorrelációt gondoltuk, ezért utánanéztünk e módszer hátterének. Elsőként a korrelációval majd az autokorrelációval és végül a térbeli autokorrelációval ismerkedtünk meg és mutattuk be jelen cikkbe. Továbbiakban az utóbbi módszerrel szeretnénk felfedni az egyes góchelyek infrastruktúra kialakítása közötti hasonlóságokat vagy különbségeket.

\section{Szakirodalmi hivatkozások}

[1] Dávid Baranyai, Ádám Török (2016): Analyzing the pedestrian and bicycling traffic in Hungary with the method of distant matrix, Road accidents prevention konferencia, Novi Sad, Szerbia, pp.11-14.

[2] Baranyai Dávid (2016): Gyalogos és kerékpáros közlekedés biztonsági és gazdasági vizsgálata, Közlekedési gazdasági szakmérnöki diplomamunka, pp. 34-55.

[3] Hunyadi László, Vita László (2005): Statisztika közgazdászoknak, Központi Statisztikai Hivatal.

[4] Kehl Dániel, Sipos Béla (2010): Regressziós modellek becslése és tesztelése Excelparancsfájl segitségével, Statisztikai Szemle, 88. évfolyam 7-8. szám, pp. 833-855.

[5] Tóth Géza (2003): Területi autokorrelációs vizsgálat a Local Moran I módszerével,Tér és Társadalom 17. évf. 2003/4. pp. 39-49..

[6] Tibor Sipos (2016): Spatial Statistical Analysis of the Traffic Accidents, Periodica Polytechnica Transportation Engineering, Volume(2017), paper 9895, DOI: 10.3311/PPtr.9895.

[7] Szakálné Kanó Izabella (2011): A gazdasági aktivitás térbeli eloszlásának vizsgálati lehetöségei, Statisztikai Szemle, 89. évfolyam 1. szám, pp. 77-100.

[8] Patrick Alfred Pierce Moran (1950): Notes on Continuous Stochastic Phenomena, Biometrika. 37. évf. 1. sz., pp. 17-23.

[9] Robert Charles Geary (1954): The Contiguity Ratio and Statistical Mapping, The Incorporated Statistician, 5 (3): 115-145. doi:10.2307/2986645. 